\title{
The Influence of Slope Angle of Stairs on Energy Consumption and Work Productivity on Male and Female Workers
}

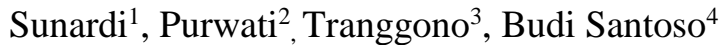 \\ Department of Industrial Engineering \\ Universitas Pembangunan Nasional "Veteran" Jawa Timur \\ Surabaya, Indonesia \\ ${ }^{1}$ gitannar@yahoo.co.id
}

\author{
Oryza Tannar ${ }^{5}$ \\ Department of Accounting \\ Universitas Pembangunan Nasional "Veteran" Jawa Timur \\ Surabaya, Indonesia
}

\begin{abstract}
Material handling can be done with the help of equipment or manually with various methods or working positions. One of the real work which we seen everyday is material handling from warehouse to truck with using stairs, where we don't know how to use slope angle by right so that it can result high productivity. The objective of the research is to know whether there are a difference of influence between the $30^{\circ}$ and $4^{\circ}$ used to carry goods from the first floor to the second floor on work productivity in male and female workers. It is assumed that the results of the study will show that workers carrying goods using $30^{\circ}$, produces to higher productivity than using $\mathbf{4 5}^{\circ}$ for both male and female workers. Male worker has a stronger endurance so it will have higher productivity than female worker. This research can contribute to theoretical understanding in the development of ergonomics and the design of work system, especially on material handling by using different slope angle of stairs on both male and female workers. Variables include the independent variables are: (1) The slope angle of stairs with two levels are $45^{\circ}$ and $30^{\circ}$, (2) Sex with two levels are male and female. And the dependent variable is work productivity of the amount of goods that can be brought $(\mathrm{kg})$ per unit time. Data analysis with inferential statistical approach Analysis of Variance (ANOVA) with 95\% significance level by using minitab software. The results show significantly that material handing using stairs with the stairs angle with the slope of $30^{\circ}$ generate higher productivity compared to when using stairs angle with slope of $45^{\circ}$ on workers at both male and female. In working time for 15 minutes male workers can move thing larger than female, namely male workers as much as $303.6 \mathrm{~kg} / 15$ minutes and female workers as much as $249.6 \mathrm{~kg} / 15$ minutes. While stairs with slope $30^{\circ}$ more ease the workload than stairs of the slope of $45^{\circ}$, namely giving results $322.8 \mathrm{~kg} / 15$ minutes for slope $30^{\circ}$, and $230,5 \mathrm{Kg} / 15$ minutes for slope of $45^{\circ}$.
\end{abstract}

Keywords- slope angle; stairs; gender; work productivity

\section{INTRODUCTION}

One of the activities of material handling in the production system is to move materials or working objects from one place to another. Material handling can be done with the help of equipment or manually with various methods or work positions, so material handling that are less precise or even incorrect will cause waste both in the use of energy and time.
Related to material handling is an activity that needs attention in the production system especially for factory buildings that have more than one floor. Although material handling can be done with the help of a tool such as an escalator but if the escalator is considered too expensive and the factory area is also not possible for only one floor or must be made for two floors or more, then making a ladder is a proper alternative to be applied. Beside of work posture in doing a job is important for increasing comfort. [1] Evaluations of discomfort, work posture, and effort provide valuable insights into possible risks in the workplace.

The problem is how much the tilt angle should be made to minimize energy consumption, and the process of fatigue can be avoided in a short time. The tilt angles with different will cause different work load and different mileage, so that the combination of both will affect duration of work and work load. [2] States that the energy consumption from start to finish runs over the running incantations at varying speeds and slopes increases with increasing the tilt angle.

Work productivity is decreased due to exhaustion of energy so that body tired conditions needs to rest or slow down [2]. The result of the research showed that at two brigdes in Bandung showed that the slope angle of stair 230 with rung height about $17.4 \mathrm{~cm}$ needed energy consumptions about $1.666 \mathrm{kcal} / \mathrm{min}$ and the slope angle of stair 39,40 with rung height about $17.4 \mathrm{~cm}$ needed energy consumptions about $2.5556 \mathrm{kcal} / \mathrm{min}[3]$.

The objective of the research is to know whether there are a difference of influence between the $30^{\circ}$ and $45^{\circ}$ used to carry goods from the first floor to the second floor on work productivity in male and female workers. It is assumed that the results of the study will show that workers carrying goods using a $30^{\circ}$ produces to higher productivity than when using $45^{0}$ for both male and female workers. Male workers have a stronger endurance so that in the same work time it will have higher productivity than female workers. It is hoped that this research can contribute to theoretical understanding in the development of ergonomics and the design of work systems, especially on material handling by using different the tilt angle on both male and female workers. That energy consumption from start to finish ran over incantations running at varying speeds and slopes increased with increasing angle of 
inclination. Furthermore, more work load can adversely affect the quality and work performance, so that the work system designed in such a way will get the best productivity and quality of work that can be achieved if the burden is within the limits of physical ability.

\section{THEORETICAL BASIS}

The measurement of physical activity based on strength and endurance is in essence not only determined by muscle strength alone, but also influenced by other subjective factors, such as: the amount of energy released, speed of work, the way and the attitude of performing work, exercise habits, sex, age, reaction power, stability, load position and direction of movement of limbs, and etc. [4] Estimated rate of energy expenditure during stairway ascent was $8.5 \pm 0.1 \mathrm{kcal} \mathrm{min}^{-1}$ during the one step ascent and 9.2 $\pm 0.1 \mathrm{kcal} \mathrm{min}^{-}$during the two step ascent

Position of work can also cause a different workload so that energy consumption is relatively different. Workload and job complexity have positive and significant impact on job stress, while job stress has a negative impact on job performance [5]. Further supported the moderation effect of job control on the relationship between workload and exhaustion [6].

Physical work resulted in energy expenditure which is closely related to energy consumption. The definition of physiological fatigue is fatigue that arises due to physiological changes in the body [2]. From a physiological point of view, the human body can be regarded as a fuel-consumptive engine, and provides output in the form of forces that are useful for carrying out daily activities. In principle, there are 5 kinds of mechanisms that the body does, namely: circulatory system, digestive system, muscle system, nervous system and respiratory system. Continuous physical work, affect the mechanisms above, either individually or simultaneously. Fatigue occurs due to the accumulation of residual products in muscle and blood circulation, where these residual products are not limiting the viability of muscle activity. Or, it might be said that these residual products affect the nerve fibers and the central nervous system, causing people to become slow to work when they are tired. So, need to improve work methods used.

The definition of the working method improvement is a systematic approach to getting a more convenient and good way of doing a job. The purpose of the improvement of work methods is to avoid various types of waste (time, human effort, raw materials, modal, etc.) or often called "work smart, not hard". It is further said that to get a good work system from an existing work system or to have a work system put forward, is one of the things to be achieved by learning some techniques that way [7]. The principles that must be considered in work system design is the economy movement, this principle is developed based on analyzing the motion study. Estimated rate of energy expenditure during stairway ascent was $8.5 \pm 0.1 \mathrm{kcal} \mathrm{min}-1$ during the one step ascent and $9.2 \pm 0.1 \mathrm{kcal} \mathrm{min}-1$ during the two step ascent [9]. Workload and job complexity have positive and significant impact on job stress, while job stress has a negative impact on job performance.

\section{RESEARCH METHODS}

The research was done on dated January 6 to February 3 2018 every Saturday begun 8 am to $5 \mathrm{pm}$ at the Laboratory of Work System Design \& Ergonomics in Industrial Engineering Department - Faculty of Engineering - UPN "Veteran" East Java with a sample of 60 people consisting of 30 women and 30 men. Both male and female workers carry goods on the same weight for $5 \mathrm{~kg}$ and working time for 15 minutes. The research was done between 9 to 12 hours.

Based on the objectives and hypotheses of the research, the variables to be studied in this study include the independent variables are: 1) stairs angle with two levels are $30^{\circ}$ and $45^{\circ}$, 2) Gender with two levels are men and women. And the dependent variables are work productivity of the amount of goods that can be brought $(\mathrm{kg})$ per unit time. The two independent variables can be combined so that the research design can be described as follows:

TABLE I. RESEARCH DESIGN

\begin{tabular}{|c|c|}
\hline $\begin{array}{l}\text { Independent Variables: } \\
\text { Treatment Combination }\end{array}$ & $\begin{array}{c}\text { Dependent Variables: Work } \\
\text { Productivity }\end{array}$ \\
\hline Male $30^{\circ}$ & 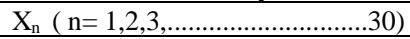 \\
\hline Female $30^{\circ}$ & 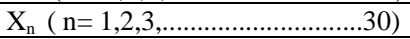 \\
\hline Male $45^{0}$ & 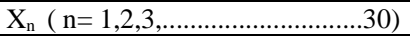 \\
\hline Female $45^{0}$ & 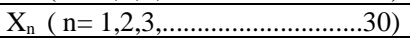 \\
\hline
\end{tabular}

Material using a box of sands about $5 \mathrm{~kg}$, and instrument that used is the meter stairs level at laboratory PSK \& Ergonomic in Industrial Engineering Department UPN "Veteran" East Java.

Data analysis is done by using inferential statistics analysis of Analysis of Variance (ANOVA) with 95\% significance level by minitab software.

Materials contain a box of sands about $5 \mathrm{~kg}$, and instrument that used is angle stairs multilevel at laboratory PSK \& Ergonomic in Industrial Engineering Department UPN "Veteran" East Java.

TABLE II. HEIGHT OF STAIRS AND RUNG

\begin{tabular}{|c|c|c|c|}
\hline Slope Angle of Stair & $\begin{array}{c}\text { Height of } \\
\text { Stair } \\
(\mathrm{cm})\end{array}$ & $\begin{array}{c}\text { Height of Rung } \\
(\mathrm{cm})\end{array}$ & $\begin{array}{c}\text { Total Rung } \\
\text { (unit) }\end{array}$ \\
\hline $30^{0}$ & 150 & 12 & 12 \\
\hline $45^{0}$ & 150 & 23 & 7 \\
\hline
\end{tabular}

Data analysis is done by using inferential statistics analysis of Analysis of Variance (ANOVA) with 95\% significance level by minitab software.

\section{Steps of Research}

The research can be done by steps as follows: 


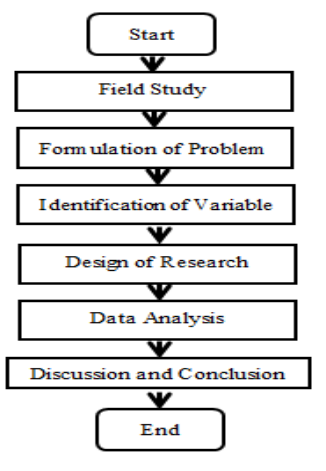

Fig 1. Steps of Research

\section{A. Research result}

The results of data processing by using minitab software shown in table 3 as follows:

\section{TABLE III. WORK PRODUCTIVITY}

\begin{tabular}{|c|c|c|c|}
\hline Treatment & $\begin{array}{l}\text { Frequency /15 } \\
\min \end{array}$ & $\begin{array}{l}\text { Frequency } \\
\text { Average / } 15 \\
\text { min /person }\end{array}$ & $\begin{array}{c}\text { Average } \\
\text { productivity } \\
\text { (kg/15 min) }\end{array}$ \\
\hline (a) & (b) & $\left(\mathrm{c}=\sum \mathrm{b} / 30\right)$ & $(\mathrm{d}=\mathrm{c} * 5 \mathrm{~kg})$ \\
\hline Male $30^{\circ}$ & $\begin{array}{l}87,75,68,71,69,69, \\
78,77,75,68,73,72, \\
72,85,84,76,71,68, \\
81,76,75,74,73,71, \\
75,78,77,76,75,74\end{array}$ & 74,76 & 373,8 \\
\hline Female $30^{\circ}$ & $\begin{array}{l}55,51,56,50,52,53, \\
58,59,56,57,54,53, \\
56,54,51,54,53,52, \\
51,52,53,55,56,54, \\
55,56,57,55,56,57\end{array}$ & 54,36 & 271,8 \\
\hline Male $45^{0}$ & $\begin{array}{l}45,47,46,46,47,48, \\
45,46,46,47,45,49, \\
46,47,48,45,46,47, \\
48,49,45,46,47,45, \\
45,49,48,48,46,49\end{array}$ & 46,7 & 233,5 \\
\hline Female $45^{0}$ & $\begin{array}{l}41,48,51,52,46,44, \\
42,43,46,49,47,41, \\
46,45,43,47,48,44, \\
45,43,42,47,46,48, \\
45,44,43,46,47,45\end{array}$ & 45,5 & 227,5 \\
\hline
\end{tabular}

Data Collected from 30 female workers and 30 male workers to move $5 \mathrm{~kg}$ materials as research subject. Table 3 shows that work productivity average of male and female workers (the average of work male and female workers) are obtained from frequency average/15 minutes/person multiplied $5 \mathrm{~kg}$.

TABLE IV. PRODUCTIVITY BASED ON GENDER AND SLOPE ANGLE

\begin{tabular}{|c|c|c|c|}
\hline & \multicolumn{2}{|c|}{ Work productivity $(\mathrm{kg} / 15 \mathrm{~min})$} & $\begin{array}{c}\text { Average } \\
(\mathrm{kg} / 15 \mathrm{~min})\end{array}$ \\
\cline { 2 - 3 } & $30^{0}$ & $45^{0}$ & 303.6 \\
\hline Male & 373.8 & 233.5 & $249, .6$ \\
\hline Female & 271.8 & 227.5 & \\
\hline $\begin{array}{c}\text { Average } \\
\mathrm{kg} / 15 \mathrm{~min})\end{array}$ & 322.8 & 230.5 & \\
\hline
\end{tabular}

To see the comparisons from viewpoint of gender and the slope angle of the stairs. Table 4 shows productivity average is $303.6 \mathrm{~kg} / 15$ minutes from male worker, and $249.6 \mathrm{~kg} / 15$ minutes from female worker. So from the gender perspective, male worker has higher work productivity than female worker. Futher productivity average is $322.8 \mathrm{~kg} / 15$ minutes from $30^{0}$ angle, and $230.5 \mathrm{~kg} / 15$ minutes from $45^{\circ}$. So from the slope angle of stairs perspective, $30^{\circ}$ has higher work productivity than $45^{\circ}$.

To Calculate energy consumption (Y), uses formula Astuti (1985), based on Pulse velocity (X) as follows:

$$
\mathrm{Y}=1,80411-0,0229038 \mathrm{X}+4,71733 \cdot 10^{-4} \mathrm{X}^{2}
$$

TABLE V. ENERGY CONSUMPTION BASED ON SLOPE ANGLE OF STAIRS AND GENDER

\begin{tabular}{|c|c|c|c|c|}
\hline \multirow{2}{*}{ Treatment } & \multicolumn{2}{|c|}{ Pulse Average } & $\begin{array}{c}\text { Subtraction of } \\
\text { pulse after and } \\
\text { before moving } \\
\text { materials }\end{array}$ & $\begin{array}{c}\text { Energy } \\
\text { consumption } \\
\text { Kcal/min }\end{array}$ \\
\hline Female $30^{0}$ & 59 & 94 & 35 & 1.5803 \\
\hline Female $45^{0}$ & 59 & 112 & 53 & 1.9153 \\
\hline Male $30^{0}$ & 70 & 130 & 60 & 2.1281 \\
\hline Male $45^{0}$ & 70 & 143 & 73 & 2.6459 \\
\hline
\end{tabular}

TABLE VI. ENERGY CONSUMPTION BASED ON GENDER AND SLOPE ANGLE

\begin{tabular}{|c|c|c|c|}
\hline \multirow{2}{*}{} & \multicolumn{2}{|c|}{ Energy consumption Kcal/min } & \multirow{2}{*}{ Average kcal/min } \\
\cline { 2 - 3 } & $30^{0}$ & $45^{0}$ & \\
\hline Female & 1.5803 & 1.9153 & 1.7478 \\
\hline Male & 2.1281 & 2.6459 & 2.387 \\
\hline $\begin{array}{c}\text { Average } \\
\text { kg/15 min })\end{array}$ & 1.8542 & 2.2806 & \\
\hline
\end{tabular}

Table 6 shows higher energy consumption of materials handling of slope angle of stairs 450 than 300 namely, about $2.2806 \mathrm{kcal} / \mathrm{minutes}$ and $1.8542 \mathrm{kcal} /$ minutes further shows higher energy consumption of materials handling of male worker than female worker namely, about $2.2806 \mathrm{kcal} /$ minutes and $1.7478 \mathrm{kcal} / \mathrm{minutes}$

Analysis of data uses analysis of varians, yit two factors design with $n$ replication [9]. Analysis of Varians (ANOVA) about work productivity from treatment of slope angle and gender by minitab software with significance level $95 \%$, are followed:

$\begin{array}{llllll}\text { Source } & \text { DF } & \text { Adj SS } & \text { Adj MS } & \text { F-Value } & \text { P-Value } \\ \text { SLOPE ANGLE } & 1 & 10138 & 10138,4 & 1047,34 * * & 0,000 \\ \text { GENDER } & 1 & 3488 & 3488,4 & 360,37 * * & 0,000 \\ \text { SLOPE ANGLE * GENDER } & 1 & 2755 & 2755,2 & 284,62 * * & 0,000 \\ & & & & & \\ \text { Error } & 116 & 1123 & 9,7 & & \\ \text { Total } & 119 & 17505 & & & \end{array}$

Fig 2. Analisis of Varians (ANOVA) about work productivity 


\section{DISCUSSION}

Slope angle of stairs be used to carry goods, significantly be influenced by productivity displacement. The slope angle $30^{0}$ gives higher result impact than slope angle $45^{\circ}$ for male and female workers (table 5). So there are interactions between gender and slope angle of stairs to gain the work result (figure 3). It's indicated that although from mileage side to slope angle $45^{\circ}$ is shorter than slope angle $30^{\circ}$, but slope angle $45^{\circ}$ can causes more exhausted that take place work way slower than slope angle $30^{\circ}$. It's shown by work frequency that getting smaller from each time after multiplied cumulatively with the goods weight. Because fatigue may result from a number of causes, including loss of muscle mass, deconditioning, nutritional deficiencies, oxygen delivery, and anemia, it should be treated comprehensively [10]. When people have a lot of energy consumption, so the fatique can occur more quickly and then naturally will decrease work rhythm. This matter formed by lactic acid from rapid metabolism process. Although alteration process from lactic acid to glycogen can recover some body energy, body fatigue cannot be resisted, if lactic ac kpid produced more than glycogen.

It means that working will more slowly than in normal condition. Further male worker has stronger endurance ability than female worker who shown that man posture bigger than woman. And also man physiologically has energy consumptions (VO2) max or aerobic capacity as well as basic metabolism bigger than woman.

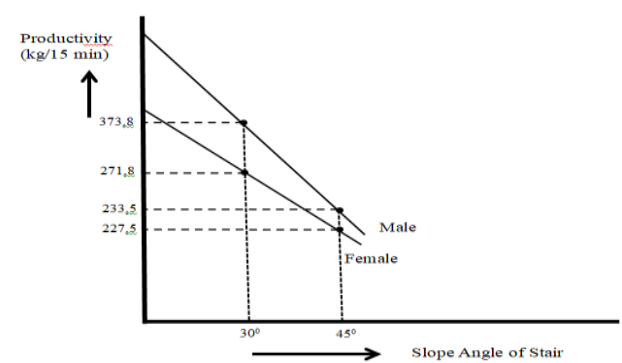

Fig 3. Interaction of Gender and Slope Angle of Stairs.

Therefore ability to survive in working that a man has longer working time than a woman. The observation of pulse before and after moving materials (carrying goods from first floor to second floor with stairs), then transformed in energy consumption to know difference between slope angle of stairs $30^{\circ}$ and $45^{\circ}$. As a result, the slope angle of stairs with $30^{\circ}$ has smaller energy consumption than $45^{\circ}$. As well as for female worker has smaller energy consumption than male worker (Table 6).

\section{CONCLUSION}

The results of the research show that slope angle $30^{\circ}$ be used to move the goods produce greater productivity than slope angle $45^{\circ}$ both male and female workers. Male worker has a stronger endurance so that in the same work time has greater productivity than female worker. To male worker with slope angle $30^{\circ}$ produces the highest productivity while female worker with slope angle $45^{0}$ produces the smallest productivity. The slope angle of stairs with $30^{\circ}$ has smaller energy consumption than $45^{\circ}$. As well as for female worker has smaller energy consumption than male worker.

\section{REFERENCES}

[1] CRC Press LLC, Handbook of Human Factors and Ergonomics Methods, New york, 2005.

[2] W.S. Marras, W. Karwowski, Taylor \& Francis Group,Fundamentals And Assessment Tools for Ergonomics and TheManagement of Musculoskeletal Disorders, Second edition, New York, USA: Elsevier, 2006

[3] A. Purnomo, "Proposed Ergonomic Strike Bridge Stairs on Station Timur Street in Bandung", INFOMATEK J., 2009

[4] I. Portoghese, M. Galletta, R.C. Coppola, G. Finco, and M. Campagna, Burnout and Workload, Among Health Care Workers: The Moderating Role of Job Control, USA: Elsevier, 2014

[5] B. Shabbir, R. Naqvi SMM, Impact of Workload and Job Complexity on Employee Job Performance with the Moderating Role of Social Support and Mediating Role of Job Stress: A Study of Travel agencies in Rawalpindi, Islamabad and AJK, 2017.

[6] I. Portoghese, M. Galletta, R.C. Coppola, G. Finco, and M. Campagna, Burnout and Workload, Among Health Care Workers: The Moderating Role of Job Control, Elsevier USA, 2014

[7] S. Konz, Work Design: Industrial Ergonomics, Worthington, Ohio, Usa, 1990, pp. 543

[8] G Lewis, Halsey, A.R David. Watkins, M Brendan. Duggan.The Energy Expenditure of Stair Climbing One Step and Two Steps at a Time: Estimations from Measures of Heart Rate, Conrad P. Earnest, United Kingdom:University of Bath, December, 2012.

[9] W. E. Ronald, H. Raymond, Science Opportunity And Statistics For Insinyur and Scientist, Fourth Edition, Bandung: ITB, 1995

[10] Evans, J. William, Lambert, P. Charles, "Physiological Basis of Fatigue,", Original Articles: Review \& Analysis: Musculoskeletal, American J. Phys. Medicine Rehabilitation, vol 86 (1) , pp S29-S46, January 2007. 